\title{
Aplikasi Penjualan Unit Sepeda Motor Berbasis Website Pada PT. Aneka Makmur Sejahtera Capem Kota Baru Pontianak
}

\author{
Cici Juniati
}

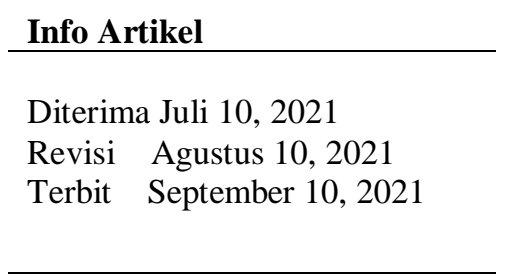

\section{Keywords:}

Motorcycle Sales application Website Web Based Sales

\begin{abstract}
PT. Aneka Makmur Sejahtera Capem Kota Baru which is one of the shops in the field of motorcycle sales services, which currently does not have data with fast presentation and there is no sales history, still recording purchase transactions on a piece of note paper and the note is given to the buyer or consumer. What hinders the work process and sees what motor unit is selected by the consumer and records it and then gives it to the consumer, after that the purchase data in the memorandum is recapitulated into the journal, making it very difficult for the cashier to recap the monthly transactions that must be given to the head of the bank every month, because the process the report recap is still looking for data one by one. Moreover, increasing sales will result in the cashier having data entry errors or cashier errors in providing information on the results of sales of motorcycle and motorcycle units to the branch head. Which uses ERD, LRS. Programming languages PHP, HTML, CSS. The database used is MySQL, and the XAMPP program package to create a local server, this application helps the process of selling motorcycle cash units that displays the name of the item, the amount or, the price of the item, and the total price, and facilitates the process of recapitulating monthly sales transaction reports based on the date of the month. year obtained from the list of sales transactions on the motorcycle unit sales application.
\end{abstract}

\section{Identitas Penulis:}

Cici Juniati

Program Studi Sistem Informasi Akuntansi Universitas Bina Sarana Informatika

Jl. Abdurahman Saleh No. 18 A Pontianak

E-mail: 11180153@bsi.ac.id

\section{PENDAHULUAN}

Teknologi pada era globalisasi ini telah berkembang ke berbagai macam bidang. Teknologi informasi berguna untuk menyediakan informasi yang bermakna dan cepat. Serta keakuratan informasi yang sangat dibutuhkan oleh kalangan masyarakat, baik dari segi perushaan, instansi, kelompok atau individu.

Perkembangan ilmu Pengetahuan dan teknologi menuntut kita membuka diri terhadap perubahanperubahan yang terjadi dan perkembangan zaman yang semakin pesat. Perusahaan yang selalalu menekankan para pengguna untuk menguasai bidang teknologi informasi dikarenakan Pesatnya perkembangan bisnis yang mengadaptasi teknologi informasi, mendorong terjadinya persaingan bisnis. Setiap pelaku bisnis bersaing untuk merebut pangsa pasar dan meraih pelanggang agar menggunakan produk atau jasa dari perusahaan merek[4].

Sistem Informasi ini sangat penting bagi perusahaan untuk mencatat transaksi penjualan dan pendapatan yang di peroleh oleh perusahaan penjualan, penerapan teknologi informasi menjadi pendukung proses bisnis seperti perusahaan dalam bidang penjualan unit sepeda motor, terutama pada dealer PT. Aneka Makmur Sejahtera Capem Kota Baru yang merupakan salah satu toko yang bergerak dibidang jasa penjualan motor Yamaha yang terletak didaerah Pontianak Jalan Prof Muhammad Yamin Kota Baru, yang dimana saat ini PT. Aneka Makmur Sejahtera tidak mempunyai data dengan sajian cepat dana belum terdapat riwayat penjualan, 
karena kasir masih melakukan pencatatan transaksi pembelian di selembar kertas nota dan kertas nota diberikan kepada pembeli atau konusmen. Ini sering terjadi menghambat proses kerja si kasir dalam dan melihat unit motor apa yang dipilih oleh konsumen dan mencatatnya kemudian diberikan kepada konsumen, setelah itu baru data pembelian dalam nota direkap ke buku transaksi penjualan atau kedalam jurnal, jadi sangat mempersulit pihak kasir dalam merekap transaksi bulanan yang wajib diberikan kepada kepala cabang tiap bulanan, karena proses rekap laporan masih mencari data satu persatu. Apalagi penjualan yang semakin meningkat akan mengakibatkan pihak kasir terjadi kesalahan pemasukan data atau kesalahan kasir dalam memberikan informasi hasil pendapatan penjualan unit motor maupun sepeda motor kepada kepala cabang.

Berdasarkan permasalahan tersebut, maka penulis membuat sebuah aplikasi penjualan unit sepeda motor berbasis website pada PT. Aneka Makmur Sejahtera Capem Kota Baru, yang menggunakan bahasa pemrograman PHP (Hypertext Proccesesor), dimana aplikasi ini dibuat pada perusahaan tersebut untuk membantu proses penjualan unit sepeda motor yang automatic menampilkan nama barang, jumlah atau, harga barang, dan total harga, serta memudahkan proses rekap laporan transaksi penjualan bulanan berdasarkan tanggal bulan tahun yang didapat dari daftar transaksi penjualan pada aplikasi penjualan unit sepeda motor berbasis web.

\section{METODE}

Metode penelitian ini terbagi menjadi 2, yaitu metode pengumpulan data dan metode pengembangan perangkat lunak. Teknik pengumpulan data adalah sebuah hal yang paling dibuttuhkan dalam melakukan peneltian karena data sangat berpengaruh pada kualitas dan hasil penelitian. Beberapa metode pengumpulan data yang dapat dilakukan dalam membuat sistem antara lain dengan melakukan observasi, wawancara dan studi Pustaka [3].

Sedangkan metode pengembangan perangkat lunak yang digunakan penulis dalam membuat aplikasi adalah metode waterfall menurut Sukanto dalam [3]. Tahapan-tahapannya adalah sebagai berikut:

\subsection{Metode Pengumpulan Data}

Berikut ini adalah penjelasan yang dilakukan oleh penulis selama melakukan pengumpulan data pada setiap tekniknya.

1. Observasi

Penulis melalukan kunjungan langsung serta melakukan pengamatan langsung ke PT. Aneka Makmur Sejahtera yang berada di Kota Baru Pontianak, yang berkaitan dengan penjualan unit sepeda motor pada PT. Aneka Makmur Sejahtera Capem Kota Baru yang beralamat Pontianak Jalan Prof Muhammad Yamin Kota Baru. Pengamatan dilakukan selama bulan 30 September 2020 - 30 Desember 2020. Hasil pengamatan memberikan informasi tentang permasalahan yang terjadi.

2. Wawancara

Wawancara juga dilakukan kepada Ibu Alyani Kristiani Selaku Operasional Manager PT. Aneka Makmur Sejahtera Capem Kota Baru berguna untuk menunjang keputusan yang diambil seperti data tambahan lainnya sepaya memperkuat opini data hasil dari observasi yang didapat.

3. Studi Pustaka

Studi pustaka dapat menunjang penulisan Tugas Akhir ini, penulis melakukan studi pustaka yang didapat pada halaman http://ejournal.bsi.ac.id dan membaca referensi-referensi lainnya seperti junal, dan tugas akhir yang memiliki kesamaan judul. Penulis juga melakukan kunjungan langsung ke perpustakaan Universitas Bina Sarana Informatika Kampus Kota Pontianak.

\subsection{Metode Pengembangan Perangkat Lunak}

Metode Waterfall adalah suatu proses pengembangan perangkat lunak berurutan, di mana kemajuan dipandang sebagai terus mengalir ke bawah (seperti air terjun) melewati fase-fase perencanaan, pemodelan, implementasi (konstruksi), dan pengujian[5]. Metode pengembangan perangkat lunak bertujuan untuk mengembangkan sistem dan memberikan panduan untuk menyukseskan proyek pengembangan sistem melalui tahapan-tahapan tertentu[2]. Dalam pengembangannya metode waterfall memiliki beberapa tahapan yang runtut yaitu 4 tahapan saja : Analisa Kebutuhan, Desain, Pengkodean, Pengujian. Adapun tahapantahapan dari model waterfall pada penulisan Tugas Akhir, diuraikan sebagai berikut:

1. Analisis Kebutuhan

Tahapan ini merupakan tahap pertama penulis datang ke PT. Aneka Makmur Sejahtera dan menanyakan tentang sistem apa saja yang dibutuhkan pada perusahaan yang bergerak di bidang penjualan unit sepeda 
motor jika sudah mendapatkan data hasil baik observasi maka dibuatkan sebuah aplikasi penjualan berbasis web yang dapat membantu perusahaan dalam mengelola transaksi penjulan di PT. Aneka Makmur Sejahtera Capem Kota Baru.

2. Desain

Dalam tahapan desain ini, proses multi langkah-langkah yang fokus pada desain pembuatan aplikasi berdasarkan hasil data yang didapat dari tahapan analisis yang nantinya akan diimplementasikan. Pada tahapan desain ini menggunakan Entity Relationship Diagram (ERD) dan Logical Record Structure (LRS) digunakan untuk pemodelan rancangan basis data, dan pemodelan diagam Unified Model Language (UML) yang terdiri dari beberapa diagram, yaitu usecase diagam, activity diagam, sequence diagram, class diagram dan deployment diagram.

3. Pengkodean

Dalam tahapan ini, dilanjutkan melakukan coding program menggunakan Bahasa pemrograman hypertext preprocessor (PHP), dan Sublime Text sebagai text editor dan XAMPP yang merupakan paket aplikasi berisikan apache, MySQL, PhpMyAdmin yang biasa untuk menjalankan website serta membuat database secara localhost serta menerapkan framework Codeigniter versi 3 sehingga pengkodean yang dihasilkan berbasis oop (oriented objek programming).

4. Pengujian

Tahapan penguji dilakukan agar aplikasi apakah ada terdapat cacat program setiap form jika tidak ada cacat program atau error maka apikasi yang telah dibuat layak diterapkan oleh pengguna.

\section{HASIL}

Antar Muka Pengguna merupakan uraian yang akan menjelaskan tampilan-tampilan pengguna. Berikut hasil rancangan antarmuka pengguna pada sistem yang dibangun.

1. Antar muka pengguna Halaman Login

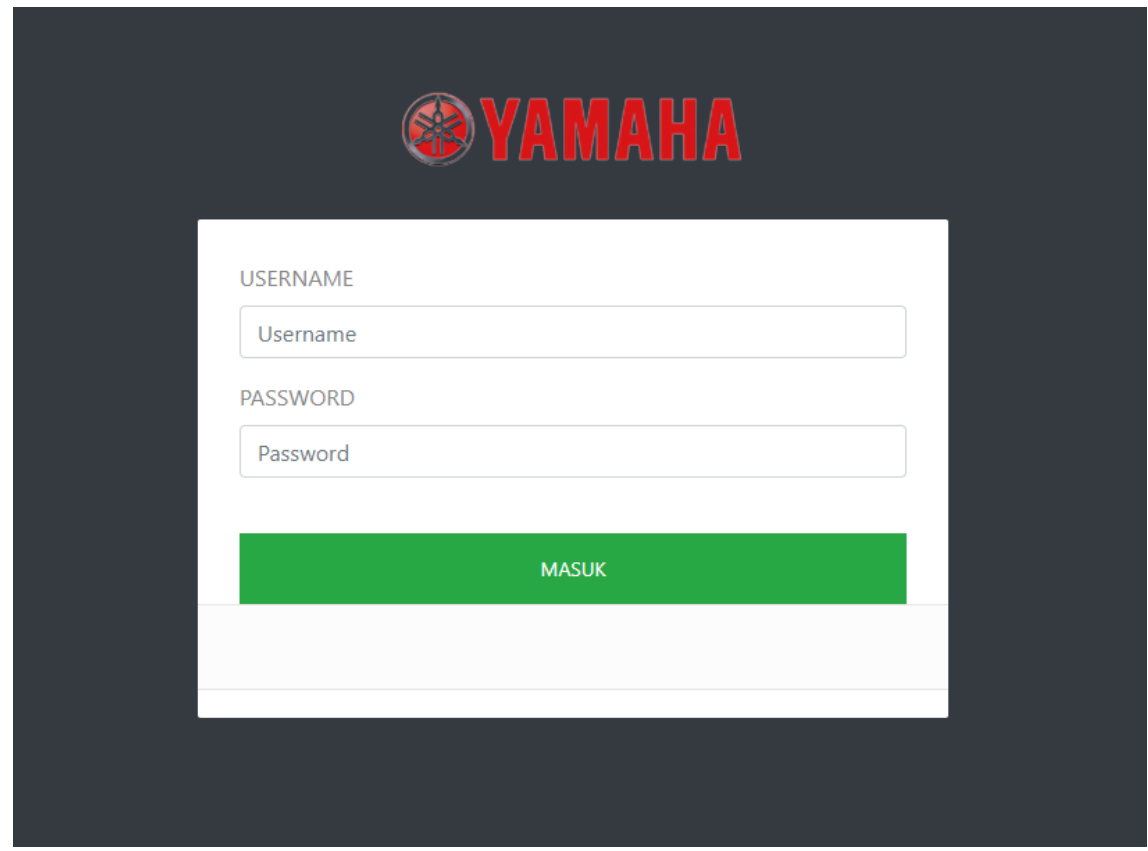

Sumber : Hasil Penelitian (2021)

Gambar 1 Antar Muka Pengguna Halaman Login

Ini merupakan antar muka pengguna halaman login yang pertama tama penguna Yamaha harus memasukan username dan password dan menekan tombol login atau masuk.

2. Antar muka Admin Halaman Beranda 


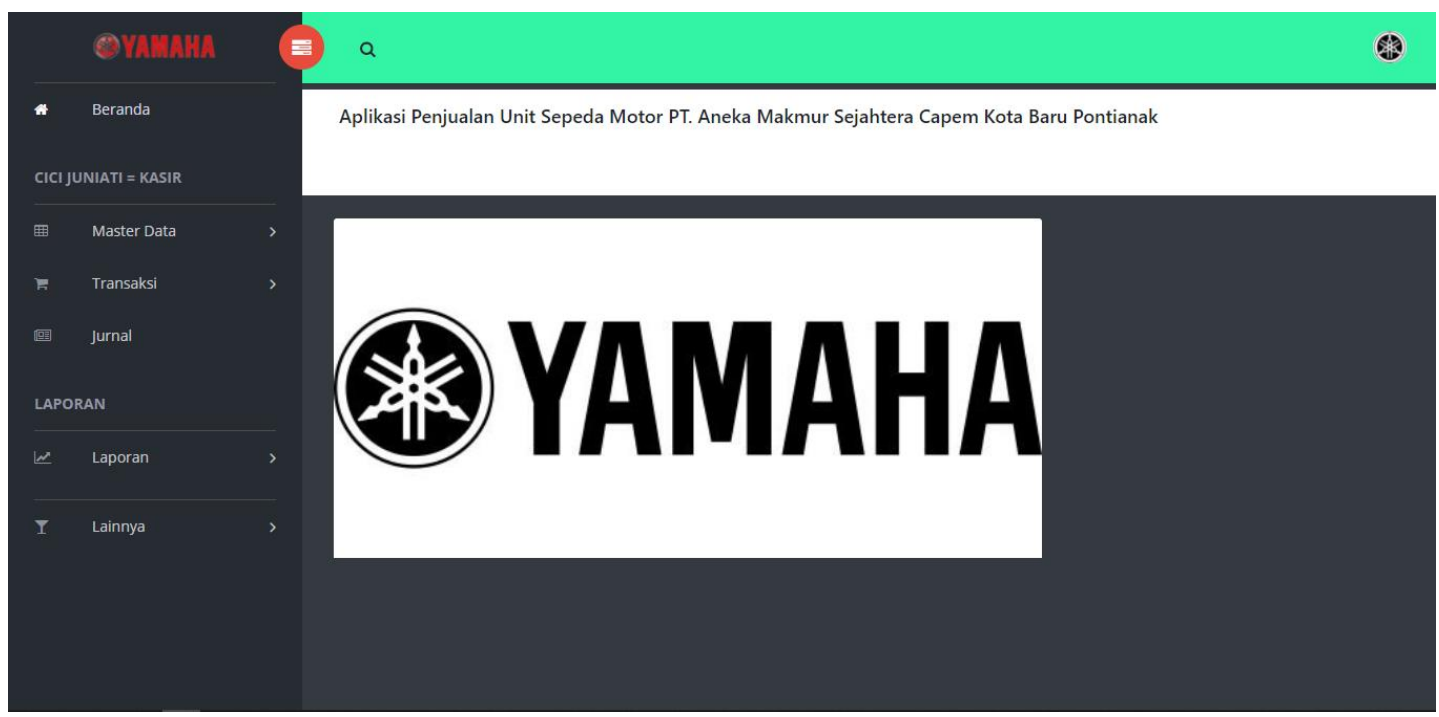

Sumber : Hasil Penelitian (2021)

\section{Gambar 2 Antar Muka Admin Halaman Beranda}

Ini merupakan halaman beranda untuk admin Yamaha yang terdapat menu beranda, master data (data motor), transaksi,jurnal,laporan dan pengaturan lainnya.

3. Antar Muka Daftar Admin

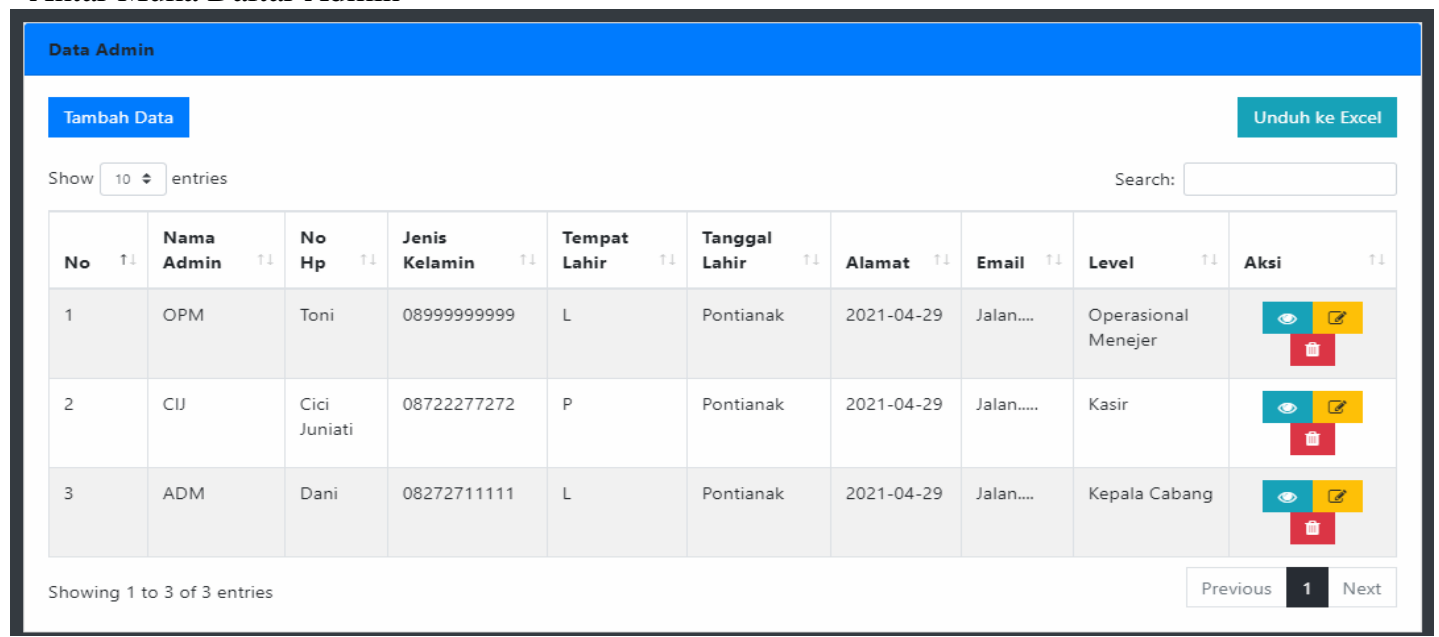

Sumber : Hasil Penelitian (2021)

Gambar 3 Antar Muka Daftar Admin

Ini merupakan tampilan daftar admin yaitu menampilkan data admin, menambah data admin, melihat detail admin mengedit data admin,menghapus data admin dan mencari data dikolom pencarian.

4. Antar Muka Form Data Admin 
Vol. 02, No. 02, September 2021, pp. 33 44

E-ISSN: 2721-7523

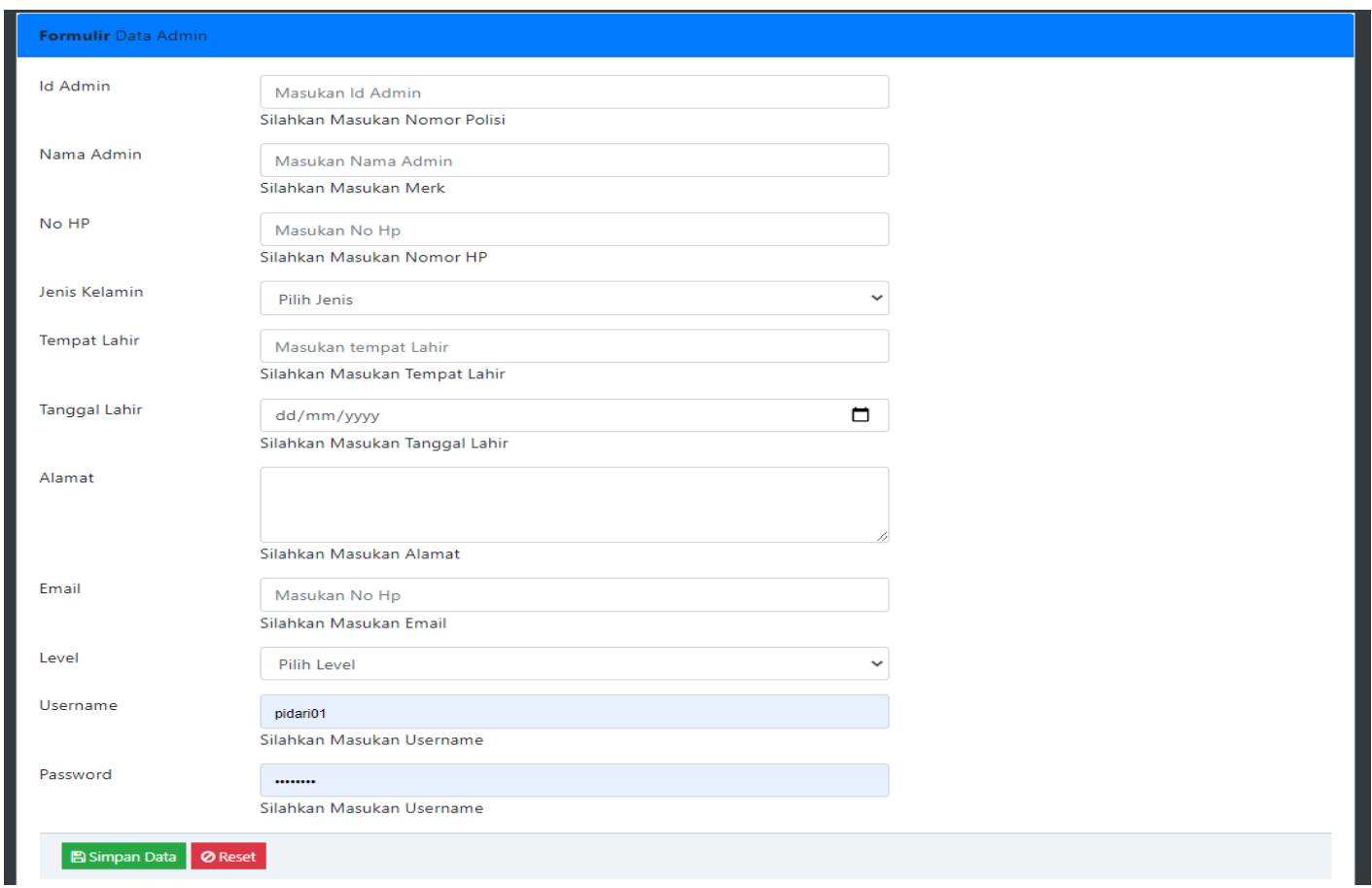

Sumber : Hasil Penelitian (2021)

5. Antar Muka Detail Admin

Gambar 4 Antar Muka Form Data Admin

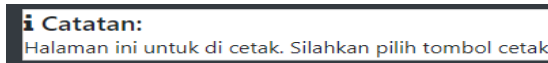

\begin{tabular}{|l|l|}
\hline Data Admin & \\
\hline & $:$ ADM - Dani \\
\hline Nama Admiin & $:$ L \\
\hline Jenis Kelamin & $:$ os272711111 \\
\hline No Hp & $:$ Pontianak \\
\hline Tempat Lahir & $:$ :2021-04-29 \\
\hline Tanggal Lahir & $:$ Jalan.... \\
\hline Alamat & $:$ Kepala Cabang \\
\hline Level & $:$ dani12 \\
\hline Username & $:$ dani12 \\
\hline Password & \\
\hline B Cetak & \\
\hline
\end{tabular}

Sumber : Hasil Penelitian (2021)

Gambar 5 Antar Muka Detail Admin 
6. Antar Muka Daftar Konsumen

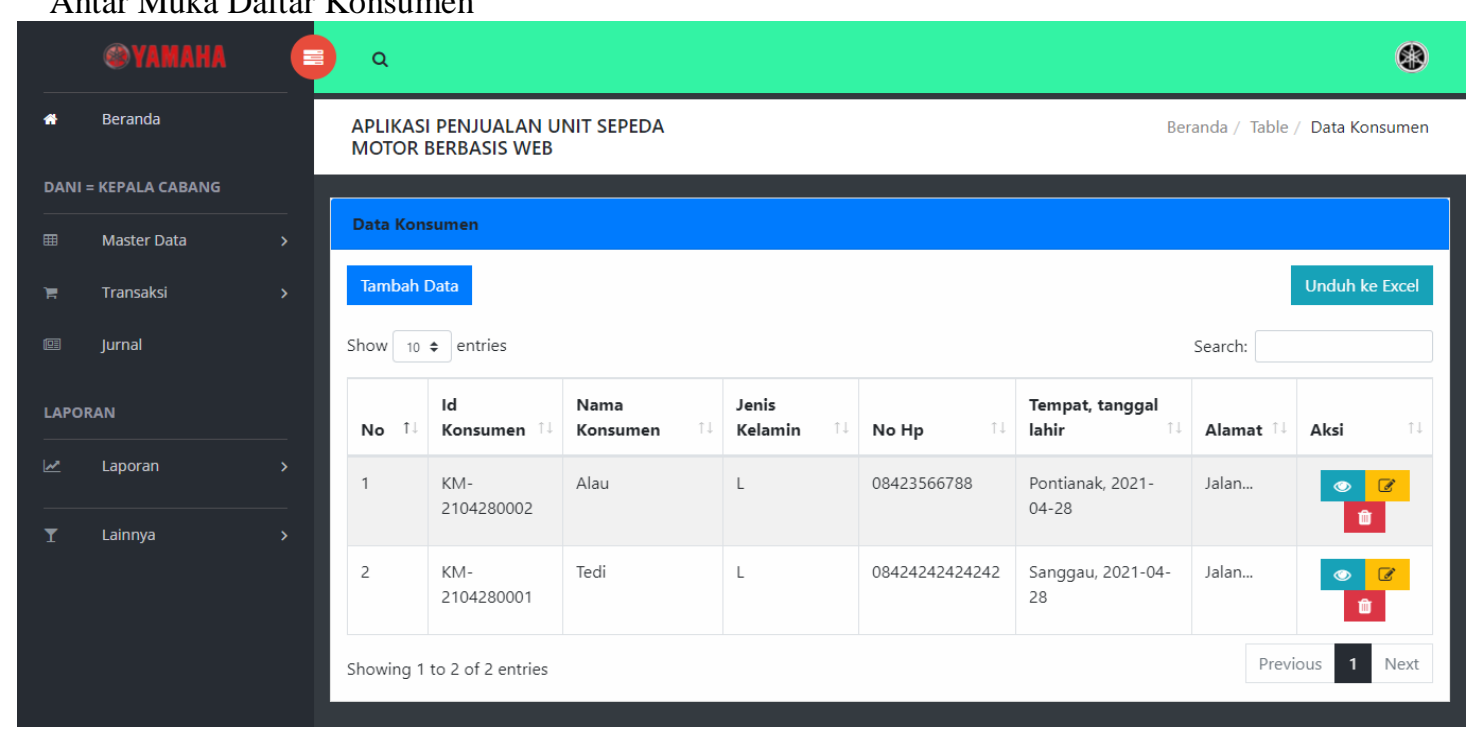

Sumber : Hasil Penelitian (2021)

Gambar 6 Antar Muka Daftar Konsumen

Antar Muka daftar konsumen pertama dapat melakukan beberapa fungsi pengelolaan seperti menampilkan daftar data konsumen, menambahkan data baru, melihat detail, mengubah data dan menghapus data, serta dapat melakukan pencarian data pada daftar data konsumen.

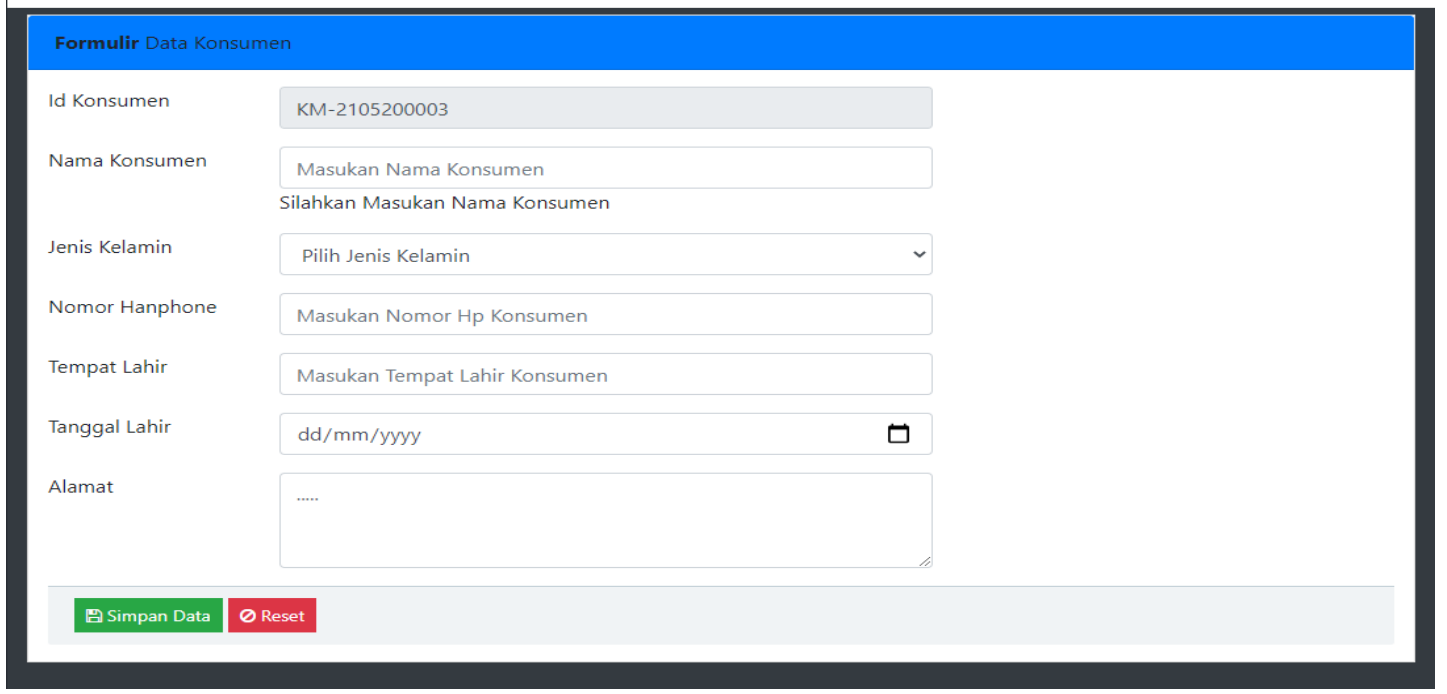

Sumber : Hasil Penelitian (2021)

Gambar 7 Antar Muka Form Konsumen 
Vol. 02, No. 02, September 2021, pp. 33 44

E-ISSN: 2721-7523

7. Antar Muka Daftar Data Motor

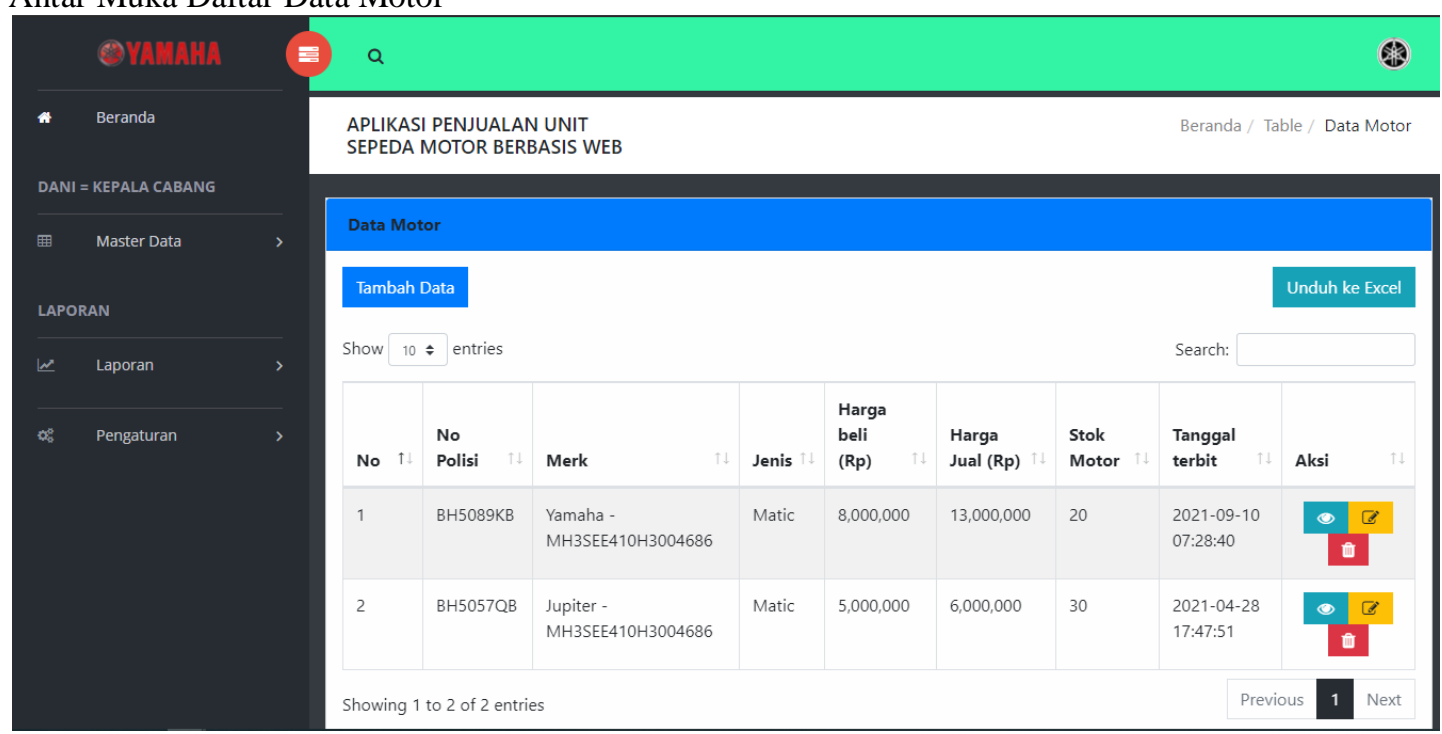

Sumber : Hasil Penelitian (2021)

\section{Gambar 8 Antar Muka Daftar Data Motor}

Antar Muka Daftar Motor dapat melakukan beberapa fungsi pengelolaan seperti menampilkan daftar data motor, menambahkan data baru, melihat detail, mengubah data dan menghapus data, serta dapat melakukan pencarian data pada daftar data motor.

8. Antar Muka Form Data Motor

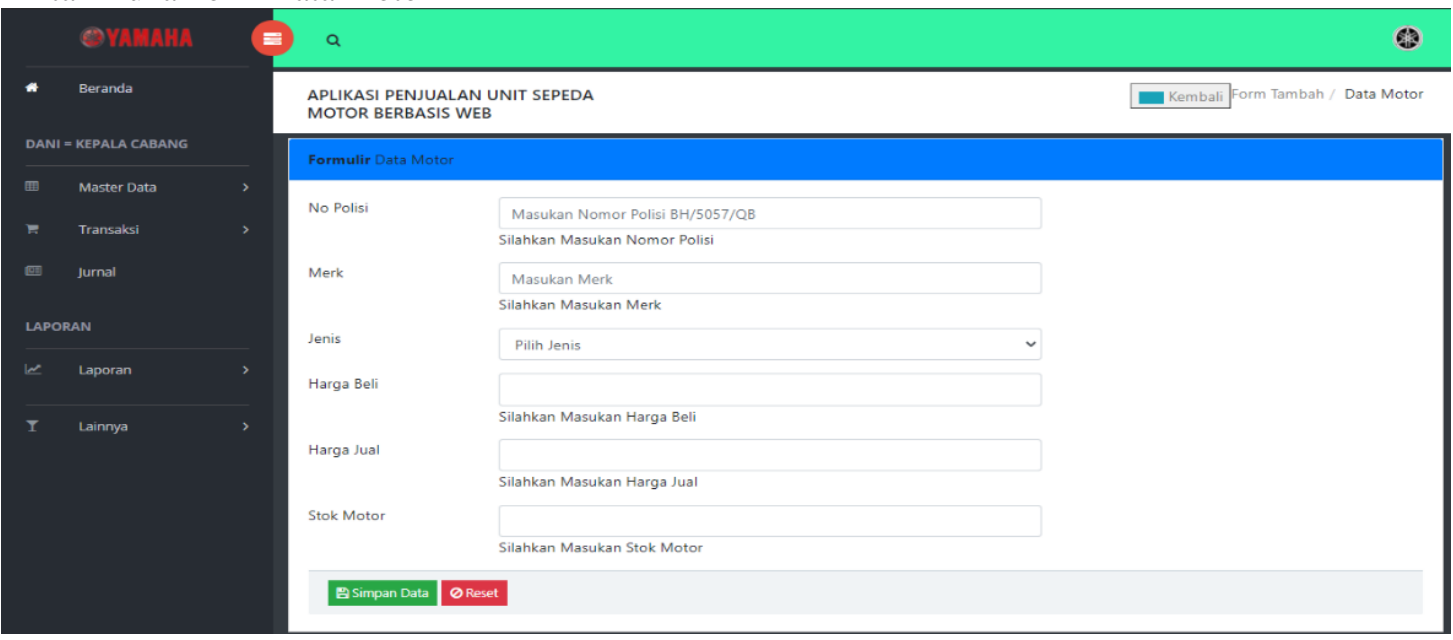

Sumber : Hasil Perancangan (2021)

Gambar 9 Antar Muka Form Data Motor 
9. Antar Muka Daftar Penjualan Cash Unit Motor

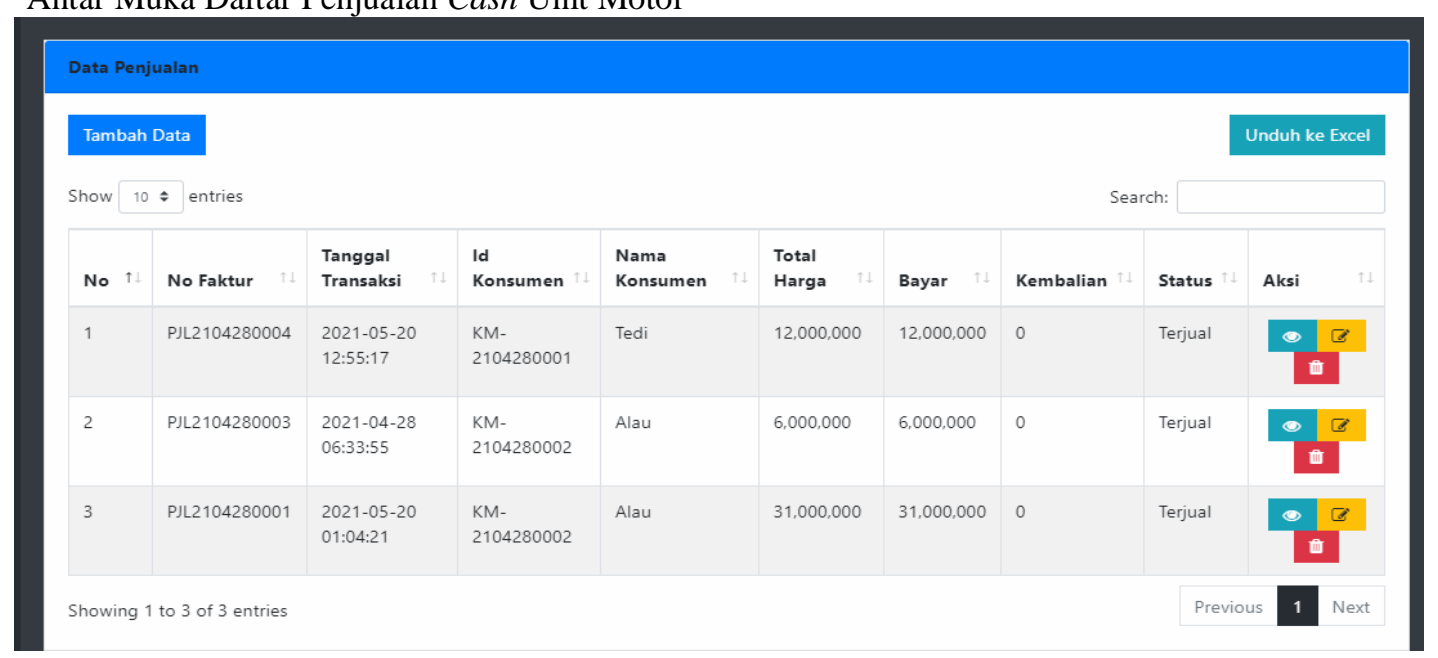

Sumber : Hasil Penelitian (2021)

Gambar 10 Antar Penjualan Cash Unit Motor

Antar Muka Daftar Penjualan Cash Unit Motor dapat melakukan beberapa fungsi pengelolaan seperti menampilkan daftar data penjualan, menambahkan data baru, melihat detail, mengubah data dan menghapus data, serta dapat melakukan pencarian data pada daftar data penjualan dan mencetak nota penjualan.

10. Antar Muka Form Penjualan Cash Unit Motor

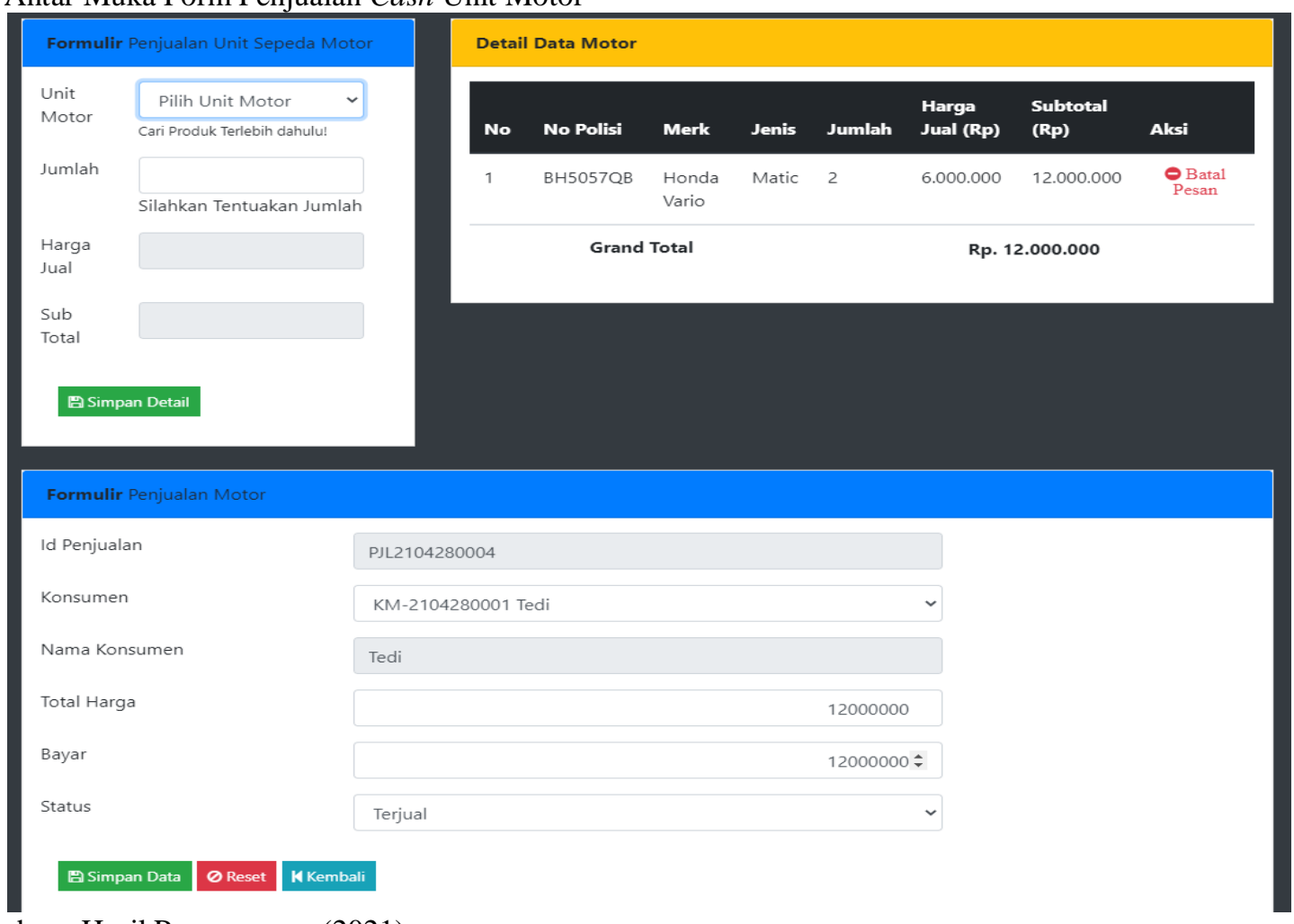

Sumber : Hasil Perancangan (2021)

Gambar 11. Antar Muka Penjualan Cash Unit Motor

Antar Muka Form Penjualan Cash Unit Motor dapat melakukan beberapa fungsi menambahkan data baru. 
11. Antar Muka Faktur Penjualan Cash Unit Motor

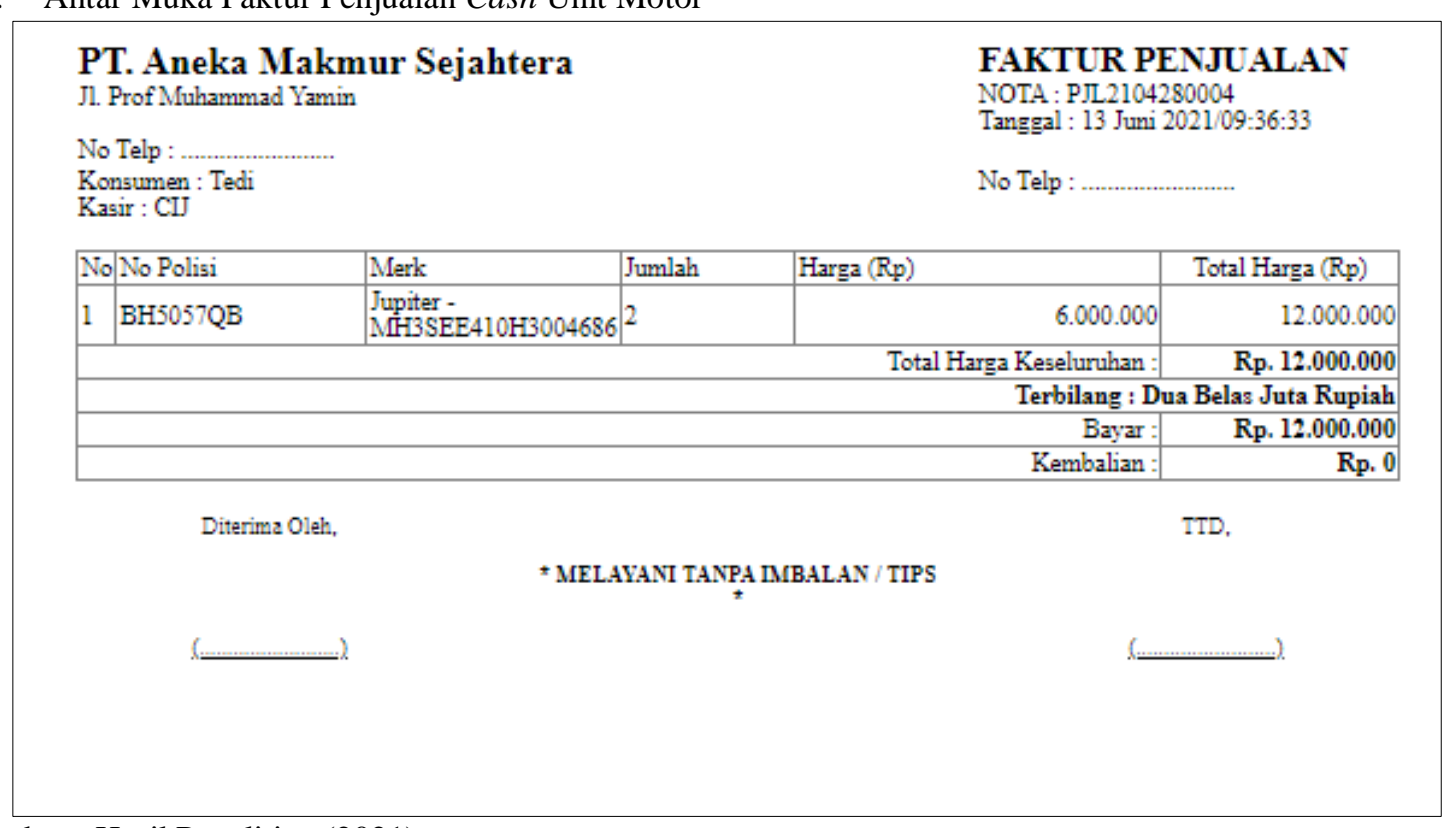

Sumber : Hasil Penelitian (2021)

Gambar 12 Antar Muka Faktur Penjualan Cash Unit Motor

12. Antar Muka Daftar Barang Masuk

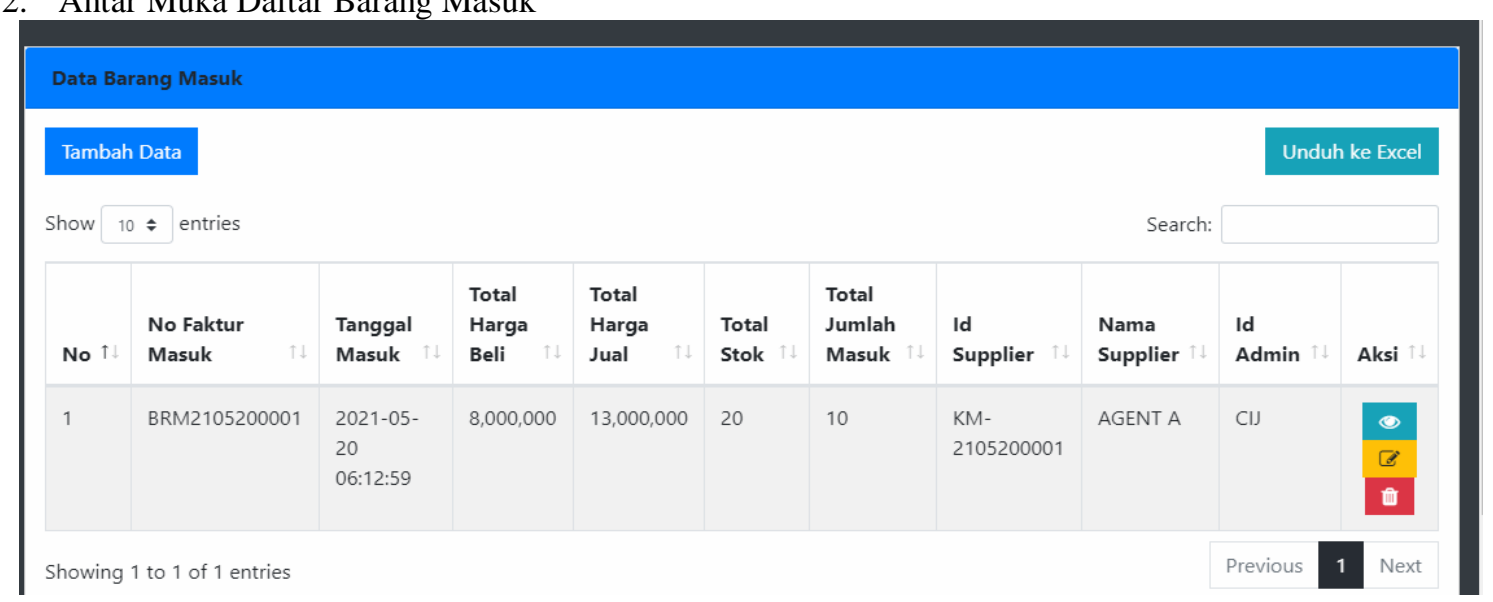

Sumber : Hasil Penelitian (2021)

\section{Gambar 13 Antar Muka Daftar Barang Masuk}

Antar Muka transaksi barang masuk dapat melakukan fungsi pengelolaan seperti menampilkan daftar transaksi tersimpan, menambahkan transaksi baru, melihat rincian transaksi, mengubah data dan menghapus data, serta dapat melakukan pencarian data pada daftar transaksi.

13. Antar Muka Form Barang Masuk 
Vol. 02, No. 02, September 2021, pp. 33 44

E-ISSN: 2721-7523

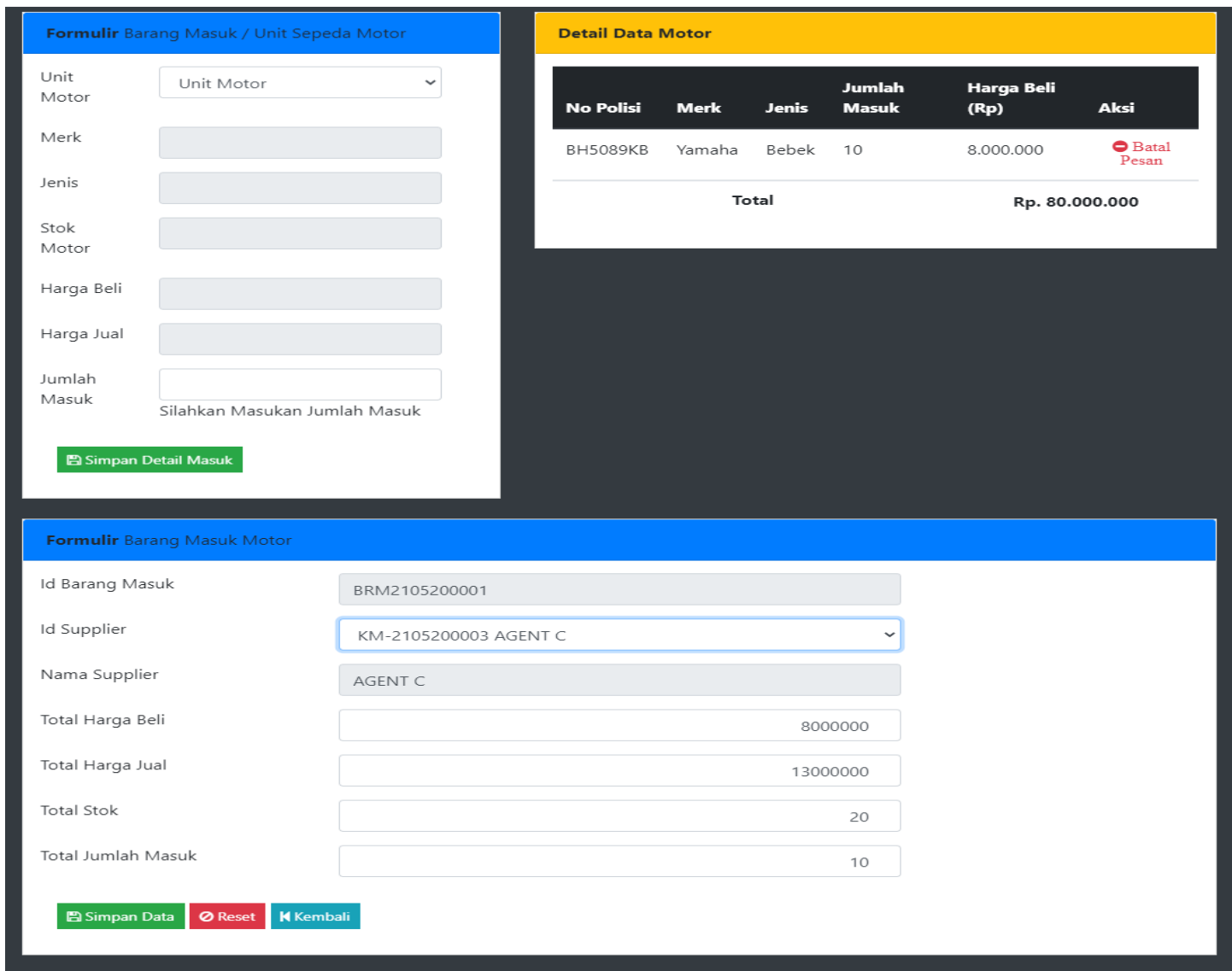

Sumber : Hasil Perancangan (2021)

Gambar 14 Antar Muka Form Produk Masuk

14. Antar Muka Faktur Barang Masuk

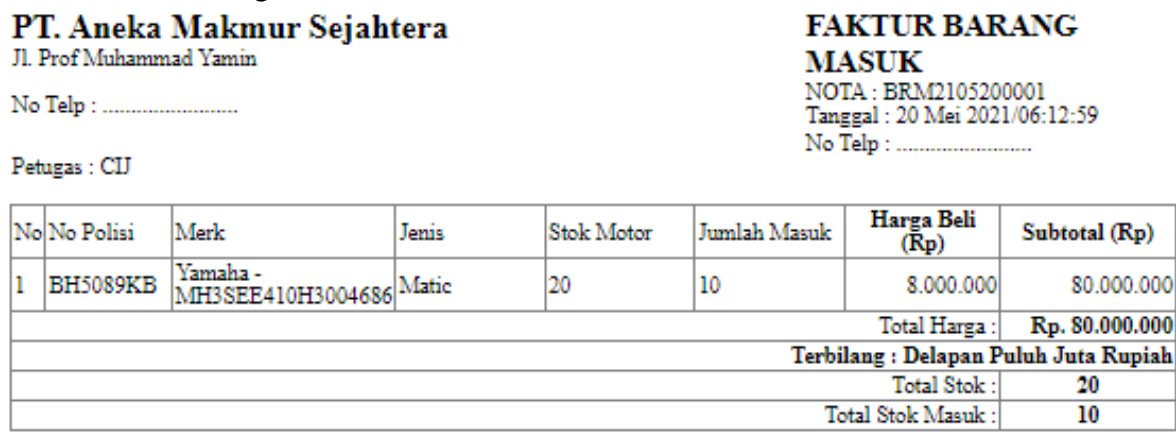

Diterima Oleh.

$$
\text { TTD. }
$$

* MEL.AYani TANPa mBaLAN / TIPS

Sumber : Hasil Penelitian (2021)

Gambar 15. Antar Muka Faktur Barang Masuk 
Vol. 02, No. 02, September 2021, pp. 33 44

E-ISSN: 2721-7523

15. Antar Muka Daftar Junal

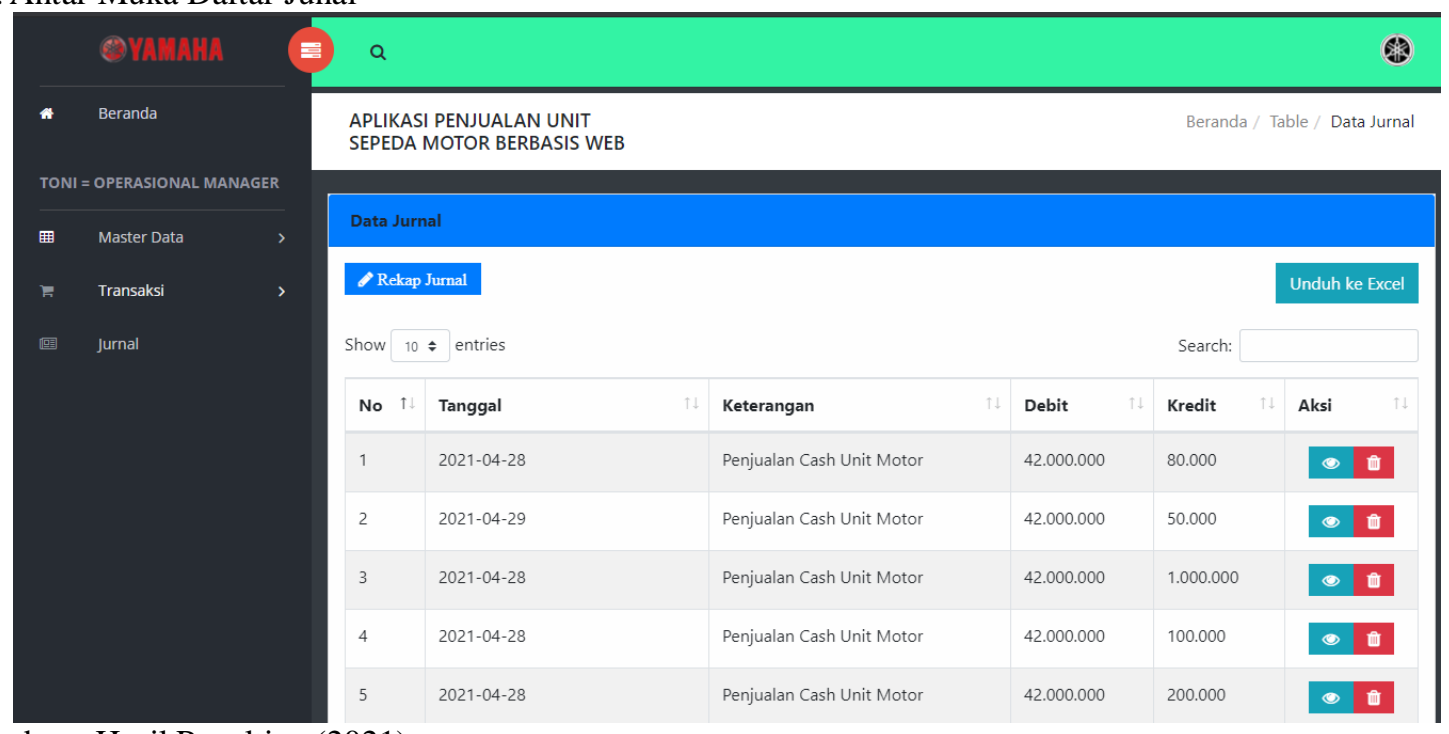

Sumber : Hasil Peneltian (2021)

16. Antar Muka Form Jurnal

\section{Gambar 16 Antar Muka Daftar Junal}

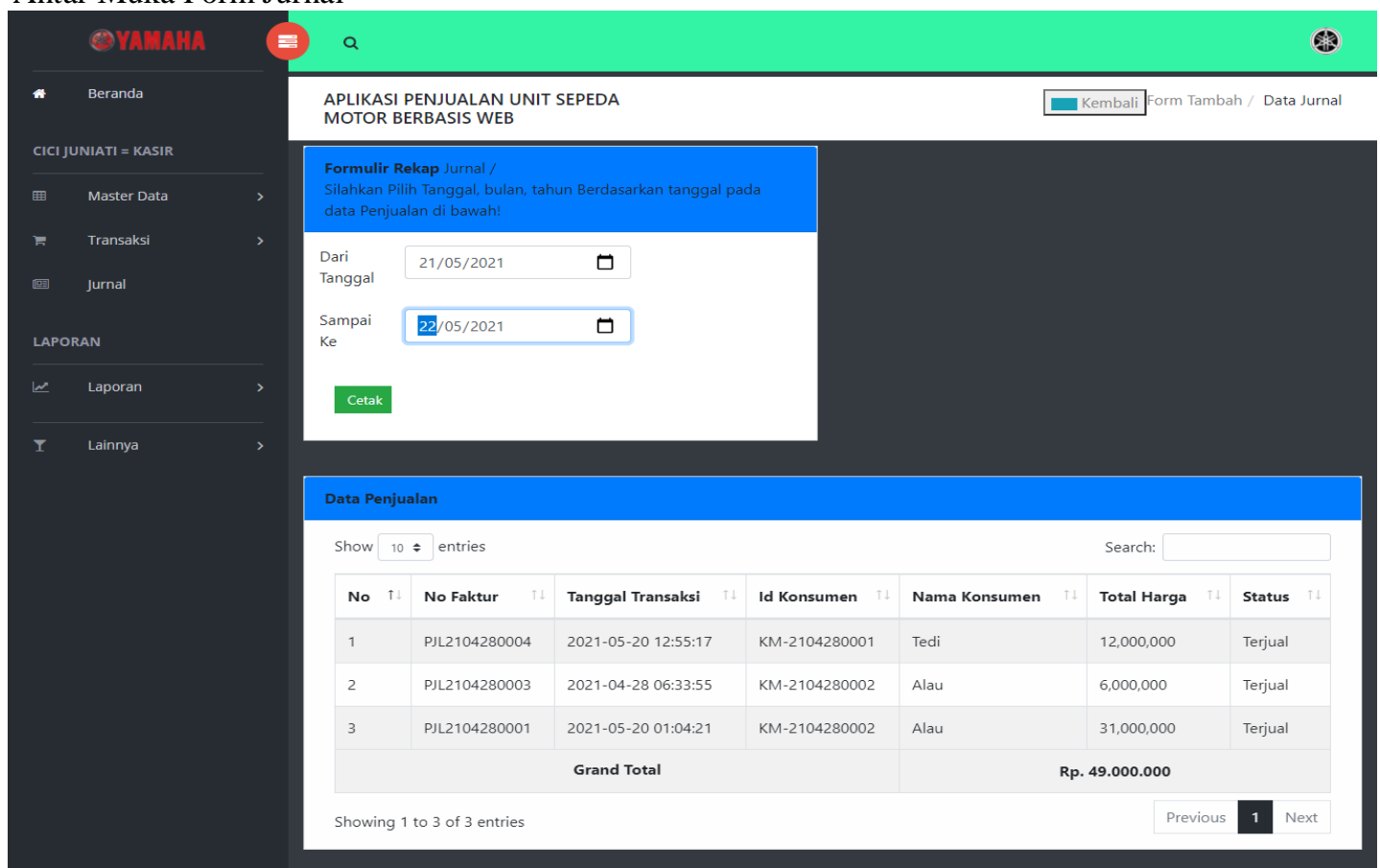

Sumber : Hasil Perancangan (2021)

\section{Gambar 17 Antar Muka Form Jurnal}

Antar Muka Pengguna Mengelola jurnal dapat melakukan fungsi pengelolaan seperti menampilkan daftar jurnal, menambahkan jurnal baru, melihat detail jurnal, mengubah data dan menghapus data, serta dapat melakukan pencarian data pada daftar jurnal.

\section{KESIMPULAN}

a. Setelah adanya aplikasi ini dapat memudahkan penginputan dalam media website penjualan unit motor 
yang bisa akses melalui internet.

b. Adanya aplikasi penjualan unit motor ini adalah solusi yang menjadikan sistem terkomputerisasi berbasis website dengan tujuan memudahkan proses pengelolaan transaksi penjualan dan pelaporan hasil penjualan, sehingga kinerja pegawai perusahaan lebih cepat dan ke arah yang lebih baik.

c. Dengan adanya aplikasi ini sistem pengelolaan terkomputerisasi akan lebih baik dibandingkan dengan pengelolaan yang belum terkomputerisasi karena lebih mudah dalam proses pendataan unit motor.

\section{REFERENSI}

[1] Abdurrazzak, Z., \& Fauzi, A. (2021). SISTEM PENUNJANG KEPUTUSAN PENERIMAAN SISWA BARU MENGGUNAKAN MULTIFACTOR EVALUATION PROCESS BERBASIS WEB. PROTEKTIF (EProsiding Teknik Informatika), 2(1), 288-297.

[2] Arizona, N. D., \& Susilowati, E. (2021). Sistem Informasi Akuntansi Simpan Pinjam Pada Sinar Kalimantan Dengan Metode Pengembangan Waterfall. Jurnal Sistem Informasi Akuntansi, 2(01).

[3] Badrul, M., \& Ardy, R. (2021). Penerapan Metode Waterfall pada Perancangan Sistem Informasi Pendaftaran Siswa Baru. J-SAKTI (Jurnal Sains Komputer Dan Informatika), 5(1), 52-61.

[4] Hartanto, A., \& Putra, B. C. (2018). Rancang Bangun Sistem Informasi Penjualan Suku Cadang dan Service Pada Iyan Motor Berbasis Object Oriented. IDEALIS: InDonEsiA JournaL Information System, 1(1), 178-184.

[5] Tristianto, C. (2018). Penggunaan metode waterfall untuk pengembangan sistem monitoring dan evaluasi pembangunan pedesaan. ESIT, 12(1), 8-22. 